\title{
Strategic decision quality in Flemish municipalities
}

\section{Bert George, Sebastian Desmidt \& Julie De Moyer}

To cite this article: Bert George, Sebastian Desmidt \& Julie De Moyer (2016) Strategic decision quality in Flemish municipalities, Public Money \& Management, 36:5, 317-324, DOI: 10.1080/09540962.2016.1194073

To link to this article: http://dx.doi.org/10.1080/09540962.2016.1194073

曲 Published online: 10 Jun 2016.

Submit your article to this journal $\pi$

Џ Article views: 104

Q View related articles $\asymp$

View Crossmark data $־$ 


\section{Strategic decision quality in Flemish municipalities}

\section{Bert George, Sebastian Desmidt and Julie De Moyer}

Strategic planning (SP) has taken the public sector by storm because it is widely believed that SP's approach to strategic decision-making strengthens strategic decision quality (SDQ) in public organizations. However, if or how SP relates to $S D Q$ seems to lack empirical evidence. Drawing on survey data from 89 Flemish municipalities, we found that $S P$ does improve $S D Q$ if a systematic approach is taken and if top policy-makers and managers, as well as lower-level staff and external stakeholders, are involved.

Keywords: Local government; stakeholder participation; strategic planning, strategic decision-making; strategic decision quality (SDQ).

As a result of New Public Management (NPM), governments worldwide have mandated public organizations at all levels of government to adopt strategic planning (SP) (Poister, 2010). This is because NPM expects that public organizations that adopt a systematic and analytic strategic decision-making process, characterized by stakeholder participation, will develop a more qualitative set of informed strategic decisions (i.e. a coherent and focused strategic plan) (Poister and Streib, 2005; Poister et al., 2013). Frequently discussed examples include the US Government Performance and Results Act 1993 and the UK Best Value Regime introduced in 2000 (Boyne $e t$ al., 2002; Poister and Streib, 2005).

Despite the assumed contribution of SP to public sector strategic decision-making, the effectiveness of SP in public organizations is debated (Pollitt, 2009). Bryson et al. (2009) argue that this debate is fueled by the fact that empirical studies focused on SP as a rational process that directly results in organizational performance (for example Andrews et al., 2009), thus illustrating a limited attention to "who was involved', 'how the process was managed' and 'what consequences ensued' (Bryson et al., 2009, p. 173). Hence, to date it remains unclear whether SP contributes to public sector strategic decisionmaking and, if so, which elements of SP account for that contribution. So assuming that SP will contribute to public sector strategic decisionmaking seems to be 'a shot in the dark' (Walker and Boyne, 2006, p. 375).

Our study addressed this issue by focusing on two constitutive elements of public sector SP: the formality of SP (Poister et al., 2013); and the level of participation during SP (Poister and Streib, 2005). Both elements are assumed to generate an information-rich decision-making environment for public organizations (Elbanna et al., 2015):

- Through a formal SP process, information about the strengths, weaknesses, opportunities and threats of the organization is systematically gathered and analysed to define strategic priorities (Poister et al., 2013).

- Through a participatory SP process, expectations of various stakeholders are incorporated into the strategic decisionmaking process so that the strategic priorities acknowledge these expectations (Osborne et al., 2013).

We examined these elements in relation to plans' strategic decision quality (SDQ) - the extent to which a strategic plan is based on qualitative and informed strategic decisions, rather than simply being an off-the-shelf compliance document (Olson et al., 2007). Data were gathered from 89 Flemish municipalities that had been required to adopt SP.

Our paper contributes to the improvement of public sector management in two main ways. First, we contribute to the literature on public sector SP by testing the relationship between SP and SDQ. Second, many countries have required local government to use SP, so our evidencebased findings from coerced Flemish municipalities have international application (Boyne et al., 2002).

\section{SP formality and SDQ}

Our first hypothesis addresses the relation between SP formality and SDQ. SP formality is the extent to which the SP process is a systematic and analytic strategic decision-making process that includes methodically developing a formal
Bert George is a PhD student in strategic management in the Faculty of Economics and Business Administration, Ghent University, Belgium.

Sebastian Desmidt is an assistant professor in strategic management in the Faculty of Economics and Business

Administration, Ghent University, Belgium.

Julie De Moyer is a consultant with The World Bank, Washington, D.C., USA. 
strategic plan, analysing internal strengths and weaknesses and external opportunities and threats, and defining strategic goals based on these analyses (Poister et al., 2013). Rational planning theory argues that the systematic and analytic nature of formal SP generates an information-rich decision-making environment, which contributes to SDQ (Boyne, 2001; Walker and Boyne, 2006). Formal SP is expected to stimulate 'decisions between alternative strategies to be taken logically on the basis of comprehensive information, rather than intuitively on the basis of incomplete or inaccurate data' (Boyne, 2001, p. 76).

Several public management scholars have argued that there is a relationship between SP formality and strategic decision-making in public organizations. For instance, Baker (1992) illustrates that, through formal SP, a rationality is injected into the strategic decision-making process of a US federal agency. Berry and Wechsler (1995) demonstrate that $82 \%$ of their sample of US state agency directors thought that formal SP helped with strategic decision-making. Ingman et al. (2002) stipulate that SP is an essential instrument for the identification of strategic priorities during strategic decisionmaking. In addition, Elbanna et al. (2015) argue that formal SP contributes to strategic decisionmaking in public organizations by increasing the likelihood that strategic decisions will actually be successfully implemented. Moreover, in the case of US municipalities, formal SP seems to be perceived as an effective strategic decisionmaking instrument and elements of a formal SP process have been found to contribute to municipal management and strategic decisionmaking (Poister and Streib, 1989, 2005). Hence:

H1: SP formality is positively related to SDQ of public organizations' strategic plan.

\section{Stakeholder participation and SDQ}

Our second hypothesis addresses the relationship between stakeholder participation during SP and SDQ. Integrative stakeholder participation theory argues that the inclusion of a variety of stakeholders during SP offers crucial insights into the expectations of key individuals and groups, thus contributing to an information-rich decision-making environment, which in turn contributes to SDQ(Hendrick, 2003; Blair, 2004). The stakeholders that are most relevant for SP include top management, top policy-makers, middle management, lower-level staffand service users (Poister and Streib, 2005).

Stakeholder participation during SP has long been a focal point of case studies in public management research. Positive effects of stakeholder participation during SP were, for instance, identified by Kemp et al. (1993) and Wheeland (1993). These case studies typically found that stakeholder participation was a contributive element of SP in public organizations. Moreover, a relationship between participation and SDQ was presumed by Alonso (2014) who indicated that public sector SP results in a set of strategic decisions that strongly affect the public interest and, in order to maximize the quality of these decisions, the expectations of key stakeholders should be incorporated into the final strategic plan. Although several case studies discuss stakeholders' contributions to SP in public organizations, large-scale empirical evidence supporting this claim is scarce (Poister et al., 2010). One highly-cited study that does present such evidence was executed by Poister and Streib (2005) in US municipalities; they found that external participation (i.e. citizens and other external stakeholders), and the participation of department heads and lower-level employees, was positively associated with an outcome variable that included enhanced strategic decisionmaking. Hence, drawing on the arguments of integrative stakeholder participation theory as well as the research evidence concerning the benefits of stakeholder participation in public sector SP, we hypothesize that:

\section{H2: Stakeholder participation during SP is positively} related to $S D Q$ of public organizations' strategic plan.

\section{Methods}

Empirical setting

As a result of legislation, Flemish municipalities were required to formulate a strategic plan by January 2014. This plan needed to contain the strategic blueprint of the municipality's 2014 2019 policy cycle, including strategic policy goals, action plans, financial impact assessments and performance indicators. Our study focused on the formality of and participation during the SP process that was used by Flemish municipalities to formulate this strategic plan; and the perceived SDQ of this strategic plan (i.e. the degree to which the plan is perceived as a set of informed strategic decisions). The empirical setting of Flemish municipalities offers two methodological advantages. First, the SP processes were all performed in a similar coercive setting and within the same time-frame, so we can accurately compare empirical findings. Second, Flemish municipalities are very homogeneous in terms of institutional context, which meant we could control for certain institutional aspects and economic conditions without having to include 
several control variables (Goeminne and Smolders, 2014).

\section{Data collection}

A three-step data-gathering procedure was employed. First, all 308 Flemish municipalities were approached and asked to provide their chief planner's contact information (i.e. the individual responsible for formulating the municipal plan). In most cases, the chief planner was either the city manager or the financial manager. Second, each chief planner was asked to identify other individuals who were centrally involved in the development of the municipal plan. Other planning team members include department heads, policy advisors, aldermen and, in some cases, the city mayor. Third, an electronic survey was sent to the chief planner and planning team members. Items concerning SP formality and stakeholder participation were incorporated into the survey for the chief planner because the chief planner is best informed on the process characteristics of the SP process (Poister and Streib, 2005; Poister et al., 2013). Items concerning SDQ were sent to both the chief planner and other planning team members because multiple informants need to be asked to avoid single-informant bias (Olson et al., 2007). As such, our study utilizes single-informant data to measure the independent variables and multiinformant data to measure the dependent variable, thus limiting potential issues of common source bias. In total, we gathered survey data from 89 chief planners and 182 planning team members, which implies that our units of analysis consist of 89 Flemish municipalities (i.e. response rate of $28.90 \%$ ).

\section{Measurement of variables}

The dependent variable (SDQ) was measured with Olson et al.'s six items (Cronbach's alpha = 0.859): overall quality; effect and results of the plan; the range of issues addressed; whether the plan is well structured; clearly elaborated; and expressed in depth (Olson et al., 2007). The first independent variable (SP formality) was measured with the four items presented by Poister et al. (2013) (see table 1). We included a fifth item-whether the municipality had conducted an analysis of external opportunities and threats during plan development (Cronbach's alpha = 0.708). The second independent variable (stakeholder participation during SP) was measured partly through the six items formulated by Poister and Streib (2005) but with additional items recommended by an academic and practitioner committee (Cronbach's alpha = 0.705 ) (see table 1). This resulted in a list of eight stakeholder groups relevant to the Flemish municipal context: the city mayor and aldermen; city council; city manager; financial manager; department heads and other senior managers; lower-level employees; citizens; and other external stakeholders.

\section{Exploratory factor analysis (EFA)}

Table 1 lists the results of our EFA. The EFA suggested that a structure of four latent constructs - not two as expected-underlies the measured independent items. These four factors explained $63.47 \%$ of the variance. The identified structure seems robust as only two items (item 1 and item 7) cross-load (a loading of 0.32 or more) on two or more factors. However, as the variables did not load strongly ( $\geq 0.50$ ) on each factor, these cross-loadings were not considered troublesome (Costello and Osborne, 2005). In addition, all items displayed moderately to strong communality with the exception of item 7 , which failed to reach the desirable factor loading of at least 0.50 (Costello and Osborne, 2005). Hence, item 7 was omitted.

The EFAindicates that 'SP formality' consists of two factors. One factor, which we label as the 'analytic dimension' of municipal SP, groups the items that measure the degree to which the municipal SP process consists of analysing strengths and weaknesses, analysing opportunities and threats, and defining strategic goals based on said analysis. A second factor, which we label as the 'systematic dimension' of municipal SP, groups the items that measure the degree to which the SP process was a systematic process that resulted in a formal strategic plan. The identified two factors correspond with rational planning theory, which argues that SP processes are typically both systematic (i.e. following a stepwise approach that results in a formal strategic plan)and analytic (i.e.conducting analysis in order to gather information and then converging said information into strategic goals) (Boyne, 2001; Andrews et al., 2009; Poister et al., 2013).

The EFA also suggests that 'stakeholder participation' consists of two factors. We labelled these 'top policy-makers and managers' (TP \& M) and 'lower-level staff and external stakeholders' (LS \& ES). Stakeholder theory typically argues that different groups of stakeholders exist based on interest and power, and managers should be aware of this distinction in order to keep stakeholder participation 'manageable' (Hendrick, 2003). Hence, the factor TP \& M represent the top layer of policy and management within a municipality. This includes the mayor and aldermen, the city manager, the 
Table 1. Exploratory factor analysis of independent variables $(N=89$ Flemish municipalities).

\begin{tabular}{|c|c|c|c|c|}
\hline Independent variables & Factor 1 & Factor 2 & Factor 3 & Factor 4 \\
\hline \multicolumn{5}{|l|}{ Strategic planning formality } \\
\hline $\begin{array}{l}\text { Item 1: We developed our municipal plan through a systematic planning } \\
\text { process }\end{array}$ & 0.459 & 0.008 & 0.136 & 0.631 \\
\hline $\begin{array}{l}\text { Item 2: } \begin{array}{l}\text { Our municipal plan was a formal strategic plan or an update of a } \\
\text { formal strategic plan }\end{array}\end{array}$ & -0.065 & -0.040 & 0.067 & 0.878 \\
\hline $\begin{array}{l}\text { Item 3: During plan development, we conducted situational analyses of } \\
\text { our municipality's strengths and weaknesses }\end{array}$ & 0.889 & 0.214 & 0.160 & -0.061 \\
\hline $\begin{array}{l}\text { Item 4: During plan development we conducted situational analyses of our } \\
\text { environment's opportunities and threats }\end{array}$ & 0.853 & 0.276 & 0.191 & -0.017 \\
\hline $\begin{array}{l}\text { Item 5: During plan development we established strategic goals and used } \\
\text { them to drive decisions and actions throughout our municipality }\end{array}$ & 0.718 & 0.172 & 0.093 & 0.226 \\
\hline \multicolumn{5}{|l|}{ Stakeholder participation } \\
\hline $\begin{array}{l}\text { Item 6: The mayor and aldermen have been centrally involved in the } \\
\text { development of our municipal plan }\end{array}$ & 0.247 & 0.271 & 0.542 & -0.007 \\
\hline $\begin{array}{l}\text { Item 7: The city council has been centrally involved in the development } \\
\text { of our municipal plan }\end{array}$ & 0.120 & 0.323 & 0.450 & -0.099 \\
\hline $\begin{array}{l}\text { Item 8: The city manager has been centrally involved in the development } \\
\text { of our municipal plan }\end{array}$ & 0.169 & -0.123 & 0.714 & 0.034 \\
\hline $\begin{array}{l}\text { Item 9: } \begin{array}{l}\text { The financial manager has been centrally involved in the } \\
\text { development of our municipal plan }\end{array}\end{array}$ & -0.189 & 0.058 & 0.824 & 0.169 \\
\hline $\begin{array}{l}\text { Item 10: Department heads and other senior managers have been centrally } \\
\text { involved in the development of our municipal plan }\end{array}$ & 0.271 & 0.119 & 0.593 & 0.134 \\
\hline $\begin{array}{l}\text { Item 11: Lower-level employees have been centrally involved in the } \\
\text { development of our municipal plan }\end{array}$ & 0.107 & 0.634 & 0.209 & -0.016 \\
\hline $\begin{array}{l}\text { Item 12: Citizens have been centrally involved in the development of } \\
\text { our municipal plan }\end{array}$ & 0.169 & 0.865 & 0.014 & 0.116 \\
\hline $\begin{array}{l}\text { Item 13: Other external stakeholders have been centrally involved in the } \\
\text { development of our municipal plan }\end{array}$ & 0.278 & 0.821 & 0.027 & -0.125 \\
\hline Cumulative variance (\%) & 19.832 & 36.657 & 53.389 & 63.474 \\
\hline
\end{tabular}

Note: Figures in bold type represent the loadings of individual items on their corresponding factors.

financial manager, and department heads and other senior managers. Because these stakeholders are typically also responsible for formulating and implementing strategic plans, these individuals should be actively involved as planning team members in the SP process. The factor LS \& ES aggregates stakeholders who do not necessarily play an active role but who are consulted during the SP process. While the inclusion of these stakeholders as core planning team members of the SP process might be unmanageable (Hendrick, 2003), they nevertheless represent an important source of information (Alonso, 2014). More specifically, lower-level employees are frequently in contact with a municipality's service users and are therefore aware of users' needs. Additionally, citizens and other external stakeholders are directly impacted by municipal plans and could therefore provide information that better aligns the plan to their needs (Osborne et al., 2013).

\section{Data analysis and results}

The analyses were conducted using $\mathrm{R}$ version 3.1.3 with the package for Partial Least Squares (PLS) Path Modeling. PLS was selected because it offers several advantages. First, PLS is a component-based approach and as such places minimal requirements on sample size and residual distributions to achieve sufficient statistical power, so it is advantageous when used with small sample sizes (Hair et al., 2012, 2013). Second, PLS allows the use of latent variables and thus simultaneously assess measurement and structural models (Chin, 1998; Hair et al., 2012, 2013). Therefore, PLS enabled us to assess the paths between our latent constructs and to further test the validity of the factor structure identified in the EFA. PLS requires the construction of a latent variable model to test the hypothesized relationships between the constructs of interest. The analysis had a twostep approach (Sanchez, 2013). In the first step, confirmatory factor analysis (CFA) was used to assess the fit of the measurement model to the data. In the second step, the relationshipsbetween the constructs are estimated and a structural model was constructed.

\section{Measurement model, descriptive statistics and} correlations

The psychometric properties of the reflective measurement model wereassessed by conducting a PLS analysis. As expected, based on the previously conducted EFA, the CFA generated five distinct factors. Four factors related to SP 
formality and participation, and one factor aggregated the items related to SDQ. Table 2 lists the PLS item loadings and cross-loadings. Item loadings and reliabilities were considered acceptable because the majority of the items scored above 0.70 (Fornell and Larcker, 1981).

Although some authors advise dropping any items with factor loadings lower than 0.70 , we decided to not to do this. None of the items in question had a loading lower than 0.40 , which is deemed acceptable by Hair et al. (2013) for exploratory studies, and there was no indication of cross-loading (i.e. all items loaded higher on the expected construct than on the other constructs). The reliability of the measurement model was further tested by calculating the composite reliability scores (CR) and the average variance extracted (AVE). Table 3 shows that the constructs had acceptable internal consistency as all CR scores exceeded the required threshold of 0.70 (Hair et al., 2013). In addition, the fact that all constructs had an AVE of $\geq 0.50$ indicates convergent validity and provides further proof that the composite measurement items have adequate item reliability.

As discussed earlier, the fact that all items included in the study loaded more strongly on their corresponding construct than other constructs is a first criterion indicating discriminant validity (see table 2). A second criterion for discriminant validity requires that the square root of the AVE scores of each variable should be higher than the bivariate correlations involving the construct (Fornell and Larcker, 1981). Table 4 shows that all constructs met this requirement.

\section{Structural model}

The second step of the data analysis process examined the significance and strength of each of the hypothesized effects by running, in $\mathrm{R}$, a PLS structural model using bootstrapping (5000 bootstrap samples). The results indicate that the included exogenous variables explain $32.8 \%(\mathrm{R} \leq)$ of the variance of SDQ. Table 5 provides detailed information about the analysed paths.

With respect to the effect of SP formality on SDQ, the study results indicate that the systematic dimension of formal SP has a positive relationship with $\operatorname{SDQ}($ path $=0.37, \mathrm{t}=3.67, p<.001)$, while the analytic dimension of formal SP is not significantly related with $\mathrm{SDQ}$ (path $=-0.03, \mathrm{t}=$ $-0.29, p>0.10)$. As such, the analysis results only partially support H1. Our results also indicate that stakeholder participation is positively related with SDQ. More specifically, the results show that involvement of TP \& M (path $=0.18, \mathrm{t}=$ $1.77, p<0.10)$ and LS \& ES (path $=0.29, \mathrm{t}=$ $2.82, p<0.01)$ is positively related with SDQ. H2 is thus fully supported. Although the nonbootstrapped path coefficient for the path between TP \& M and SDQ is only significant at the $p<0.10$, the fact that the $95 \%$ bootstrapped confidence interval for the path coefficient does not include zero, provides support for the significance of this path.

\section{Discussion}

The relationship between public sector SP and SDQ is one of the key assumptions underlying

Table 2. PLS factor loadings.

\begin{tabular}{|c|c|c|c|c|c|}
\hline & $S D$ & $A D$ & $T P$ E $M$ & $L S E E^{2} E S$ & $S D Q$ \\
\hline Item 1 & 0.99 & 0.40 & 0.33 & 0.14 & 0.46 \\
\hline Item 2 & 0.42 & 0.04 & 0.10 & -0.10 & 0.07 \\
\hline Item 3 & 0.30 & 0.94 & 0.35 & 0.40 & 0.24 \\
\hline Item 4 & 0.31 & 0.95 & 0.39 & 0.46 & 0.32 \\
\hline Item 5 & 0.42 & 0.75 & 0.26 & 0.30 & 0.23 \\
\hline Item 6 & 0.26 & 0.33 & 0.79 & 0.37 & 0.37 \\
\hline Item 8 & 0.22 & 0.24 & 0.66 & 0.10 & 0.16 \\
\hline Item 9 & 0.15 & 0.05 & 0.66 & 0.06 & 0.17 \\
\hline Item 10 & 0.26 & 0.37 & 0.68 & 0.22 & 0.27 \\
\hline Item 11 & 0.12 & 0.30 & 0.25 & 0.54 & 0.13 \\
\hline Item 12 & 0.13 & 0.36 & 0.28 & 0.92 & 0.33 \\
\hline Item 13 & 0.07 & 0.43 & 0.29 & 0.92 & 0.38 \\
\hline Item 14: Our municipal plan has had a positive effect on our municipality & 0.24 & 0.20 & 0.36 & 0.46 & 0.81 \\
\hline $\begin{array}{l}\text { Item 15: Relative to what I expected, the results of our municipal plan have } \\
\text { been positive }\end{array}$ & 0.31 & -0.04 & 0.21 & 0.02 & 0.61 \\
\hline Item 16: Overall, I feel that the quality of our municipal plan was good & 0.55 & 0.26 & 0.34 & 0.27 & 0.85 \\
\hline Item 17: Our municipal plan covered the maximum range of relevant issues & 0.26 & 0.29 & 0.29 & 0.34 & 0.87 \\
\hline $\begin{array}{l}\text { Item 18: Our municipal plan was well structured and reflective of interrelations } \\
\text { and intra-relations among the relevant issues }\end{array}$ & 0.42 & 0.35 & 0.36 & 0.33 & 0.91 \\
\hline Item 19: Our municipal plan was expressed in depth & 0.35 & 0.24 & 0.24 & 0.25 & 0.77 \\
\hline
\end{tabular}

Notes: Figures in bold type represent the loadings of individual items on their corresponding factors. SD = systematic dimension of formal strategic planning; $\mathrm{AD}=$ analytic dimension of formal strategic planning; TP \& $\mathrm{M}=$ top policy-makers and managers; LS \& ES = lower-level staff and external stakeholders; SDQ = strategic decision quality. 
Table 3. Descriptive statistics.

\begin{tabular}{|c|c|c|c|c|c|c|}
\hline & $\begin{array}{l}\text { Theoretical } \\
\text { range }\end{array}$ & $\begin{array}{l}\text { Actual } \\
\text { range }\end{array}$ & Mean & $S D$ & $C R$ & $A V E$ \\
\hline Systematic dimension* & 6 & 4 & 4.938 & 1.002 & & \\
\hline Analytic dimension & 6 & 5 & 5.611 & 1.080 & 0.91 & 0.78 \\
\hline Top policy-makers and managers & 6 & 3.25 & 6.388 & 0.672 & 0.79 & 0.52 \\
\hline Lower-level staff and external stakeholders & 6 & 5.33 & 4.247 & 1,200 & 0.85 & 0.66 \\
\hline SDQ & 6 & 3.16 & 4.867 & 0.594 & 0.92 & 0.65 \\
\hline
\end{tabular}

Table 4. Inter-construct correlations and average variance extracted (AVE).

\begin{tabular}{|c|c|c|c|c|c|}
\hline & 1 & 2 & 3 & 4 & 5 \\
\hline \multicolumn{6}{|l|}{ 1. Systematic dimension } \\
\hline 2. Analytic dimension & $0.38 * * *$ & 0.78 & & & \\
\hline 3. Top policy-makers and managers & $0.33 * *$ & $0.39 * * *$ & 0.49 & & \\
\hline 4. Lower-level staff and external stakeholders & 0.12 & $0.45 * * *$ & $0.32 * *$ & 0.66 & \\
\hline 5. Strategic decision quality & $0.45 * * *$ & $0.30 * *$ & $0.38 * * *$ & $0.37 * * *$ & 0.65 \\
\hline
\end{tabular}

Notes: The latent variable 'systematic dimension' consists of two variables, which means that the AVE cannot be reliably calculated.

Off-diagonal elements are correlations: $* p<0.05 ; * p<0.01 ; * * *<0.001$.

The diagonal values in bold type are the square root of the average variance extracted (AVE). Values should be larger than off-diagonal elements in order to satisfy discriminant validity requirements.

Table 5. PLS path modeling results.

\begin{tabular}{|c|c|c|c|c|c|}
\hline \multirow[t]{2}{*}{ Path from: } & \multirow[b]{2}{*}{$\begin{array}{l}\text { Path } \\
\text { coefficient }\end{array}$} & \multirow[b]{2}{*}{ t-value } & \multirow[b]{2}{*}{$p$-value } & \multicolumn{2}{|c|}{$\begin{array}{l}95 \% \text { bootstrapped } \\
\text { confidence intervals }\end{array}$} \\
\hline & & & & Low & High \\
\hline Systematic dimension & 0.37 & 3.67 & $0.00 * * *$ & 0.04 & 0.54 \\
\hline Analytic dimension & -0.03 & -0.29 & 0.77 & -0.23 & 0.19 \\
\hline Top policy-makers and managers & 0.18 & 1.77 & $0.08^{*}$ & 0.04 & 0.36 \\
\hline Lower-level staff and external stakeholders & 0.29 & 2.82 & $0.01 * *$ & 0.14 & 0.43 \\
\hline
\end{tabular}

Notes: Reported $p$-values are one-tailed: *significant at $0.10 ; * *$ significant at $0.05 ; * *$ significant at 0.001 .

NPM and has resulted in a widespread, and often coerced, adoption of SP by public sector organizations. Our research focused on the formality of the SP process and level of participation during the SP process because these two elements ofSP are, based on rational planning theory and integrative stakeholder participation theory, thought to contribute to SDQ. Based on an exploratory analysis and CFA, we found that, in the case of Flemish municipalities, two additional dimensions underlie SP formality (i.e. a systematic and analytic dimension), as well as stakeholder participation (i.e. participation of the top policy and management team, and participation of lower-level staff and external stakeholders). By constructing a PLS structural model, our findings suggest that NPM's assumption has some validity, but is contingent on the systematic dimension of SP and the extent to which top policy-makers and managers, as well as lower-level staffand external stakeholders, are involved in SP. Our findings have a number of implications for public management.

Whereas rational planning theory argues that SP formality is positively related to $\mathrm{SDQ}$ (Boyne, 2001; Walker and Boyne, 2006), our findings only partly support this statement. More specifically, we found evidence that developing a formal strategic plan through a systematic process (i.e. the systematic dimension of SP) contributes to SDQ. However, we did not uncover evidence that the definition of strategic goals based on a SWOT analysis (i.e. the analytic dimension of SP) has any significant effect on SDQ. Nevertheless, the emphasis of Flemish legislation has been on the formulation of strategic goals based on a SWOT analysis. A possible reason for this finding could be that the definition of strategic goals based on a SWOT analysis might have been a matter of compliance, addressing the requirements and norms of central authorities (Taylor, 2011), as opposed to a truly analytic and strategic exercise. Typically, the analytic dimension of SP requires effort and expertise, time and resources, as well as education and training, and, as was the case with other coerced SP processes such as Best Value, these prerequisites might not have been present in 
Flemish municipalities (Boyne and GouldWilliams, 2003). However, our findings do imply that following a systematic process and developing a formal strategic plan contributes to SDQ. This finding seems to tie in with the recommendation of Ugboro et al. (2011), Kemp et al. (1993) and Baker (1992) to define upfront SP guidelines and clarify expectations. More specifically, chief planners and other planning team members can, in advance, clarify the systematic process that will be followed during SP in order to ensure that the methodical, stepwise approach of SP is safeguarded throughout the planning process. Additionally, chief planners and other planning team members should, in advance, agree upon the nature of the output resulting from the systematic SP process, namely to produce a formal strategic plan that has an organizationwide impact and not just a compliance document that lacks any strategic dimension (Baker, 1992; Kemp et al., 1993; Ugboro et al., 2011).

Moreover, our findings support integrative stakeholder participation theory because the participation of both top policy-makers and managers, as well as lower-level staffand external stakeholders, during SP is positively related to SDQ (Hendrick, 2003). Top policy-makers and managers represent the most senior politicians and managers within a municipality (for example the mayor and the city manager). Our research has revealed the importance of including this top layer of the municipality during SP, which is in line with the literature on vertical strategic alignment (Andrews et al., 2012). More specifically, SP is a time- and resource-consuming practice for top policy-makers and managers in public sector organizations. By actively involving theseindividuals in SP, public sector organizations can ensure that the SP process, as well as the strategic plan, 'fit the management style of the organization' (Ugboro et al., 2011, p. 110). As such, SP includes top policy-makers and managers' requirements, which contributes to SDQ. Apart from the top politicians and managers, who are arguably the 'usual suspects' involved in public sector SP, our findings suggest that a participatory SP process should also involve LS \& ES. This is in line with the service-dominant approach to public management (Osborne et al., 2013). More specifically, public organizations deliver a range of services to citizens and other external stakeholders. The first point of contact between the organization and these service users is often with lower-level staff. Hence, in order to ensure that the needs of service users areincluded in strategic plans, both lower-level staff, citizens and other external stakeholders need to be consulted. Thus, by including these three groups of stakeholders, SP 'generates basic information about current and future needs that can then support policy formulation' (Osborneetal., 2013, p. 142).

\section{Limitations}

Although our study contributes to the debate on the effectiveness of public sector SP, some limitations need to be noted. First, our study was based on a cross-sectional survey, longitudinal data could complement our findings and offer more robust empirical evidence. Second, although we collected survey data from both chief planners and other planning team members, this was perceptual data. By incorporating archival data, future research could anticipate some of the issues associated with common method bias.

\section{Conclusion}

We examined the effectiveness of SP in public sector organizations by investigating the relationship between a formal and participatory SP process and SDQ in a sample of 89 Flemish municipalities. Factor analysis indicated that a formal SP process consisted of a systematic and analytic dimension, while a participatory SP process consisted of participation by top policymakers and managers, as well as lower-level staff and external stakeholders. By constructing a PLS structural model, we found that:

- The systematic dimension of formal SP contributes to SDQ, but the analytic dimension does not-a finding which opposes the arguments of rational planning theory.

-The participation of both top policy-makers and managers, as well as lower-level employees and external stakeholders contributes to SDQ-a finding which supports the arguments of integrative stakeholder participation theory.

Our findings thus suggest that SP can certainly contribute to SDQ in public organizations as argued by proponents of NPM. However, this contribution is contingent on both the systematic and the participatory nature of the SP process.

\section{References}

Alonso, Á. I. (2014), The shaping of local selfgovernment and economic development through city strategic planning. Lex Localis, 12, 3, pp. 373391.

Andrews, R. et al. (2009), Strategy formulation, strategy content and performance. Public 
Management Review, 11, 1, pp. 1-22.

Andrews, R.etal. (2012), Vertical strategicalignment and public service performance. Public Administration, 90, 1, pp. 77-98.

Baker, E. J. (1992), Strategic planning in a U.S. federal agency. Long Range Planning, 25, 5, pp. 73-79.

Berry, F. S. and Wechsler, B. (1995), State agencies' experience with strategic planning. Public Administration Review, 55, 2, pp. 159-168.

Blair, R. (2004), Public participation and community development. Public Administration Quarterly, 28, 1, pp. 102-147.

Boyne, G. A. (2001), Planning, performance and public services. Public Administration, 79, 1, p. 73.

Boyne, G. A. and Gould-Williams, J. S. (2003), Planning and performance in public organizations. Public Management Review, 5, 1, pp. 115-132.

Boyne, G. A. et al. (2002), Best value-total quality management for local government? Public Money E Management, 22, 3, pp. 9-16.

Bryson, J. M., Crosby, B. C. and Bryson, J. K. (2009), Understanding strategic planning and the formulation and implementation of strategic plans as a way of knowing. International Public Management Journal, 12, 2, pp. 172-207.

Chin, W. W. (1998), The partial least squares approach to structural equation modeling. In George A. M. (Ed), Modern Methods for Business Research (Lawrence Erlbaum), pp. 295-336.

Costello, A. B. and Osborne, J. W. (2005), Best practices in exploratory factor analysis. Practical Assessment Research E Evaluation, 10, 7, pp. 1-9.

De Bruijn, H. and Van Helden, G. J. (2006), A plea for dialogue driven performance-based management systems. Financial Accountability $\varepsilon^{\circ}$ Management, 22, 4, pp. 405-423.

Elbanna, S., Andrews, R. and Pollanen, R. (2015), Strategic planning and implementation success in public service organizations. Public Management Review. DOI 10.1080/14719037.2015.1051576.

Fornell, C. and Larcker, D. F. (1981), Evaluating structural equation models with unobservable variables and measurement error. Journal of Marketing Research, 18, 1, pp. 39-50.

Goeminne, S. and Smolders, C. (2014), Politics and public infrastructure investments in local governments. Local Government Studies, 40, 2, pp. 182-202.

Hair, J. F. et al. (2012), An assessment of the use of partial least squares structural equation modeling in marketing research. Journal of the Academy of Marketing Science, 40, 3, p. 414-433.

Hair, J. F.etal. (2013), Partial least squares structural equation modeling. Long Range Planning, 46, 12, pp. 1-12.

Hendrick, R. (2003), Strategic planning environment, process, and performance in public agencies. Journal of Public Administration Research and Theory, 13, 4, pp. 491-519.

Ingman, D., Kersten, J. and Brymer, T. (2002), Strategic planning that uses an integrated approach. Public Management, 84, 4, pp. 16-18.

Kemp, E. J., Funk, R. J. and Eadie, D. C. (1993), Change in chewable bites: applying strategic management at EEOC. Public Administration Review, 53, 2, pp. 129-134.

Olson, B. J., Parayitam, S. and Bao, Y. (2007), Strategic decision making: the effects of cognitive diversity, conflict, and trust on decision outcomes. Journal of Management, 33, 2, pp. 196-222.

Osborne, S. P. et al. (2013), A new theory for public service management? American Review of Public Administration, 43, 2, pp. 135-158.

Poister, T. H. (2005), Strategic planning and management in state departments of transportation. International Journal of Public Administration, 28, 13-14, pp. 1035-1056.

Poister, T. H. (2010), The future of strategic planning in the public sector. Public Administration Review, 70, pp. s246-s254.

Poister, T. H., Pasha, O. Q. and Edwards, L. H. (2013), Does performance management lead to better outcomes? Public Administration Review, 73, 4, pp. 625-636.

Poister, T. H., Pitts, D. W. and Edwards, L. H. (2010), Strategic management research in the public sector. American Review of Public Administration, 40, 5, pp. 522-545.

Poister, T. H. and Streib, G. (1989), Management tools in municipal government. Public Administration Review, 49, 3, p. 240.

Poister, T. H. and Streib, G. (2005), Elements of strategic planning and management in municipal government. Public Administration Review, 65, 1, pp. $45-56$.

Pollitt, C. (2009), Approaches to control-the poverty of 'what's hot and what's not'. Public Money E Management, 30, 1, pp. 7-8.

Sanchez, G. (2013), PLS Path Modeling with $R$ (Trowchez).

Taylor, J. (2011), Strengthening the link between performance measurementand decision making. Public Administration, 89, 3, pp. 860-878.

Ugboro, I. O., Obeng, K. and Spann, O. (2011), Strategic planning as an effective tool of strategic management in public sector organizations. Administration E Society, 43, 1, pp. 87-123.

Walker, R. M. and Boyne, G. A. (2006), Public management reform and organizational performance. Journal of Policy Analysis $\mathcal{E}^{\circ}$ Management, 25, 2, pp. 371-393.

Wheeland, C. M. (1993), Citywide strategic planning. Public Administration Review, 53, 1, pp. 65-72. 